\title{
Will Florida be saved?
}

\author{
Robert G. Johnson
}

Department of Earth Sciences, University of Minnesota, Minneapolis, Minnesota 55455

glenjay@bitstream.net

\begin{abstract}
The state of Florida is typical of all the low-lying densely populated coastal areas around the world that are threatened by present and future rising sea level. These coastal areas will become destructively flooded by sea level rise due to melting of the world's glacial ice if fossil fuel consumption and resulting global warming are not strongly limited. Efforts to achieve this limitation in a timely way might not be successful because of cultural inertia, opposition by vested interests, and the difficulties in developing alternative sources of renewable energy on a large scale. However, the rising sea level could be reversed to a more rapidly falling sea level at least temporarily if a previously unrecognized tipping point in the changing climate is reached in coming decades. This tipping point is the onset of rapid new glacial ice sheet growth in northeastern Canada, Greenland, and the Barents Sea. The cause would be an order of magnitude increase in regional precipitation. Much evidence for that event is found in the geological records of the initiation of the last ice age $120,000 y r s$ ago. The precursors for a similar future event are in place and are identified in modern oceanic records. These precursors include the increasing salinity of the Mediterranean Sea and the observed increasing penetration of the Spitsbergen-Atlantic Current into the polar ocean, which suggests that the tipping point may be reached before the end of this century. If so, the flooding may occur on only a small scale. However if so, a sharp 500yr cooling would be expected in eastern Canada and northern Europe, and greenhouse warming elsewhere would continue unless fossil fuel usage is reduced. This paper supports the suggestion by Giff Miller and Anne de Vernal in a 1992 letter to Nature that global warming and an ice age may occur simultaneously.
\end{abstract}

\section{Indexing terms/Key words}

Sea level rise, Oceanic flooding, Ice age initiation, Climate change, Tipping point, Coastal inundation. Academic discipline

Climate

Subject

Natural science

Method/Approach

Analysis of data and application of conceptual model to suggest future climate change.

\section{INTRODUCTION}

The 2015 conference of United Nations in Paris addressed the problem of global greenhouse warming by agreeing to voluntary reductions in fossil fuel use. This could be a first step toward the goal of reversing the trend of rising greenhouse temperatures caused by increasing concentrations of $\mathrm{CO}_{2}$ in the atmosphere. Regardless of any future success in limiting fossil fuel use, our world society is not yet motivated to move rapidly in that direction, and it is likely that some significant sea level rise and flooding losses of the world's coastal infrastructure will occur. The prospect of serious flooding on a 21 st century time scale, and subsequent longer term disastrous losses, might be avoided if a new ice age glaciation is triggered in northeastern Canada in the near future. Because of the general acceptance of observed greenhouse warming, proposing the possibility of a new ice age will elicit skeptical reactions, and a brief review of the history and context of the idea is appropriate.

Fifty years ago the onset of a new ice age seemed quite near at hand. At that time, the Milankovich hypothesis[1] that Northern Hemisphere glaciation was governed by variations of northern high-latitude orbitally-controlled summer insolation was widely accepted. Orbitally-controlled solar insolation is now diminishing in the arctic where new glaciation begins. Today's arctic summer insolation is similar to that when the last ice age began 120,000yrs ago, and summer temperatures in the arctic fifty years ago were lower than at the Holocene maximum a few thousand years ago. Therefore the next ice age was thought to be imminent. Since that time Rind et al.[2] have shown by careful numerical modeling that in the present climate the orbital cooling anticipated by Milankovitch would not be able to initiate new glaciation in Canada. In addition Wunsch[3] has shown that there is only a small correlation between variations of orbital insolation accurately calculated by A. Berger[4] and variations of the often-used oxygen isotope ratio proxy for changes in glacial ice volume. These results have greatly weakened the Milankovitch hypothesis in its original simplistic form. Beyond Milankovitch, the general opinion today is that global climate warming would prohibit the initiation of a new ice age.

That prohibition could fail if future events validate a hypothesis of ice age initiation caused by a cascade of oceanic salinity changes that would bring about a quite different high latitude regional climate at the ice age threshold[5]. This hypothesis is supported by the record of events that accompanied the start of the last great ice age. The new scheme retains diminishing orbitally-controlled Northern Hemisphere summer insolation as 
the root cause of the ice age initiation. But the critical factor is the reduction of summer insolation at the lower latitude of northern Africa. The resultant cooling there diminishes the African monsoon strength[6], thus decreasing river inflow to the Mediterranean Sea and increasing its salinity. The higher Mediterranean salinity started a chain of oceanic salinity changes 120,000yrs ago, leading to 500 years of rapid Canadian ice sheet growth that accelerated the start of the last great ice age. The growth was enabled by an order of magnitude increase in annual snowfall under continually cloudy skies. When the ice sheet growth began, oceanic temperatures in the ice-free sea west of Greenland were much warmer than today $[7,8,5]$ and additional atmospheric cooling there was not a factor. Therefore modern climate warming may be unable to prevent the start of new glaciation in northeastern Canada. If this triggering occurs, a rapid fall in sea level due to accumulation of glacial ice on land like that which occurred 120,000yrs ago would save Florida and other populated areas near sea level. This paper sketches out the threat to Florida and outlines the oceanic changes that suggest possible new ice age glaciation in the 21 st century.

\section{[1] THE THREAT OF NEAR- AND LONG-TERM SEA LEVEL RISE}

\section{[1.1] Florida's near-term risk}

The latest IPCC report from the intergovernmental panel on climate change predicts a probable world sea level rise of almost one meter by the year 2100 . Florida is particularly vulnerable to the resulting flooding because most of the peninsula lies near present sea level and real estate development often occurs close to present high tide level. Miami is one example. Using a mid range prediction for the rise of sea level, in January of 2016 NOAA's Climate Central predicted at least one annual flood exceeding $2 \mathrm{~m}$ (six feet) above the 2012 mean high tide line at Miami, with a mean high tide in 2100 that could be $1.1 \mathrm{~m}$ higher than in 2012 . That estimate of sea level rise may be too small however, because the rate of loss from the Greenland ice sheet seems to be accelerating over the last few years as temperatures rise and new measurements are reported. By the year 2100 the higher daily and lunar monthly high tide levels and possible hurricane storm surges will likely destroy much of Miami and other Florida real estate that lies near the high tide line. Even if world nations succeed in achieving a timely reduction of fossil fuel consumption to a low level, $\mathrm{CO}_{2}$ concentrations in the atmosphere cannot be rapidly reduced. The rate of melting of the Greenland glacial ice would tend to remain high, and its melt water contributions to rising sea level would continue with an ever increasing risk for much of Florida's population.

\section{[1.2] Near-term melting of Greenland ice}

As the world temperatures rise, the melting rate of glacial ice sheets is expected to accelerate. We are beginning to see that effect in Greenland where a complete melting of its great ice sheet would raise sea level by about $5 \mathrm{~m}$ (six feet). Loss of Greenland ice is now probably the bigger threat than loss of antarctic glacial ice because arctic temperatures are rising much faster than those in the antarctic. Several years ago the net annual loss of Greenland ice was hardly measurable. Now satellite observations show an annual loss of ice from most of the ice sheet area. According to Wikipedia and its cited references, three parts of the Greenland ice sheet are showing even more spectacular evidence of major ice loss. The Jacobshavn glacier in the middle of western Greenland has a catchment area that drains $6.5 \%$ of the entire Greenland ice sheet. Its large observed annual loss of about 35 billion tonnes of ice bergs are attributed to both surface melting and the presence of warmer seawater beneath the terminus. The Petermann glacier in northwestern Greenland is less studied, but in 2010 a $260 \mathrm{~km}^{2}$ piece calved off in its fjord. In the fjord rifts or cracks are advancing toward the terminus suggesting massive calving in the near future. There is a $750 \mathrm{~km}$-long subglacial canyon extending southward from its fjord, probably carrying much subglacial drainage.

The Zachariae Isstrøm glacier at latitude $78^{\circ} \mathrm{N}$ in northeastern Greenland drains a catchment area that has been estimated to hold ice of a $0.5 \mathrm{~m}$ world sea level rise equivalent. This glacier is of particular interest because its terminus, the toe, is rapidly retreating into the deeper water of its subglacial channel[9]. The subglacial channel is connected to a broad central part of Greenland where the ice sheet base rests on land below sea level. If the grounding line reaches this central area, a large subglacial front would become exposed to somewhat warmer Atlantic seawater. Melting then would carve out the heart of the Greenland ice sheet at a greatly accelerated rate, possibly in only a few centuries. Even on a shorter 21st century time scale, the accelerating loss of Greenland ice may cause a sea level rise in excess of the current predictions.

\section{[1.3] Long-term possibilities}

Looking ahead a few centuries without fossil fuel limitation, the picture is even more bleak because ice sheets in Antarctica would also eventually experience large ice losses. Significant loss would begin with the West Antarctic ice sheet because it is largely resting on the bottom in deep water and is potentially unstable due to buoyant forces. Satellite scans of Florida surface elevations derived from Google Earth data suggest the results in Table 1 that show the percent of the Florida peninsula that would be lost as a function of various amounts of sea level rise. 


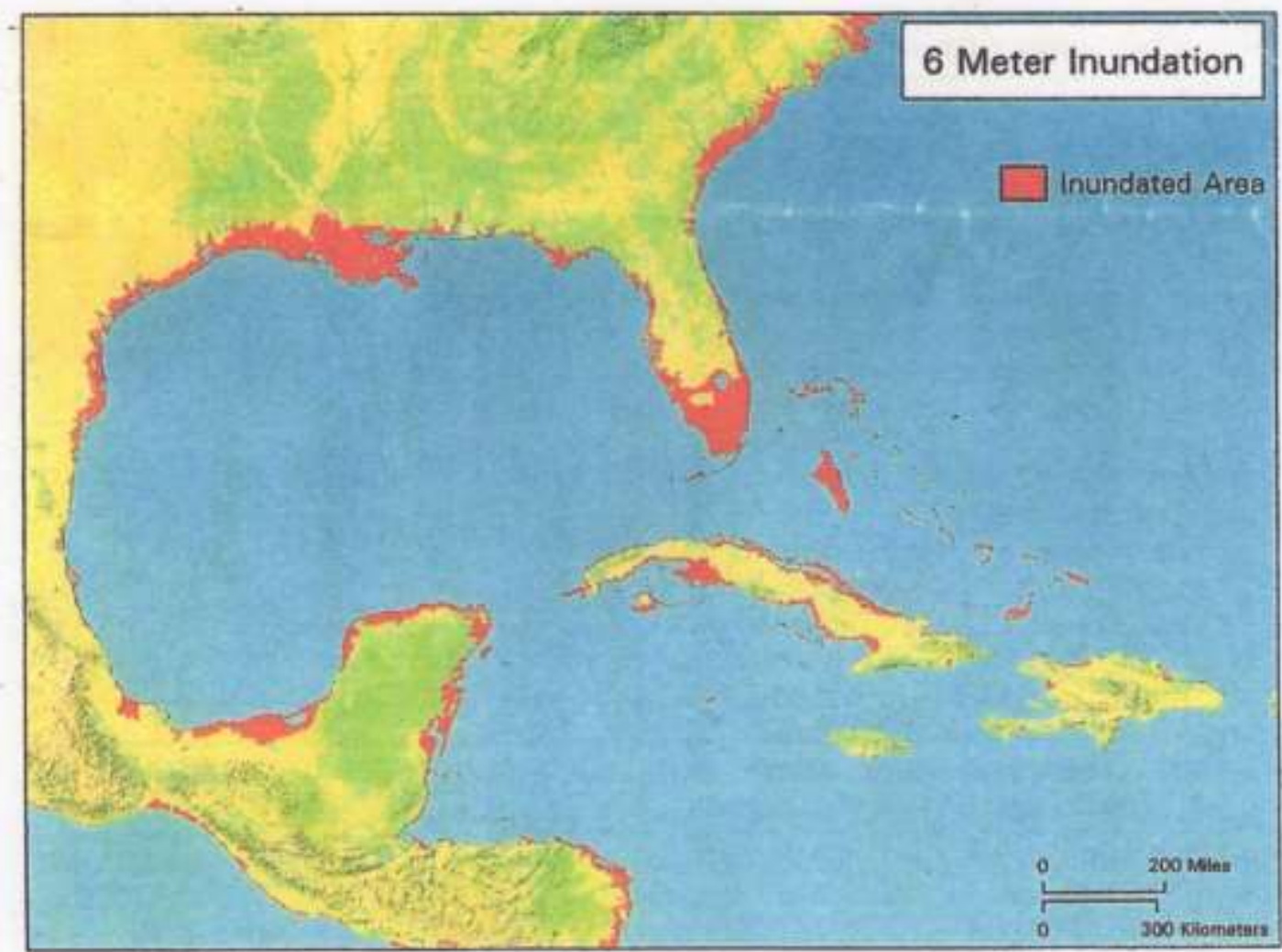

Figure 1: Inundation of coastal areas (red) by a $6 \mathrm{~m}$ sea level rise as reported in Natural Earth by Tom Patterson, U.S. National Park Service. This is approximately the rise expected if all of the Greenland ice sheet melts.

The percent inundated includes both the area of permanent inundation and the estimated area subject to destructive flooding. Figure 1 shows the inundation caused by a $6 \mathrm{~m}$ rise for coastal Florida, the southeastern U.S., the coastal regions of the Gulf of Mexico, and the Caribbean. Figure 2 shows what little remains of the Florida peninsula after a $20 \mathrm{~m}$ sea level rise. The $20 \mathrm{~m}$ rise is almost as great as estimated amounts associated with the Pliocene warm interval that occurred about three million years ago when much ice in Antarctica was lost[10, 11]. Table 1 shows the percent of the Florida peninsula inundated by several amounts of world sea level rise. Such inundation losses are a discouraging prospect, but if the tipping point of new Canadian ice sheet growth is reached, the rising sea level could soon be reversed by a spectacular change in regional climate.

\section{Table 1: Examples of inundation for different amounts of sea level rise}

\begin{tabular}{|c|c|c|c|}
\hline $\begin{array}{l}\% \text { of Florida } \\
\text { peninsula } \\
\text { inundated }\end{array}$ & $\begin{array}{l}\text { World } \\
\text { sealevel } \\
\text { rise }(\mathrm{m})\end{array}$ & $\begin{array}{l}\text { s.1. rise due to } \\
\text { Greenland ice } \\
\text { lost }(\mathrm{m}, \%)\end{array}$ & $\begin{array}{l}\text { 5.1. rise due to } \\
\text { Antarctic ice } \\
\text { lost }(\mathrm{m}, \%)\end{array}$ \\
\hline 14 & 3 & $1.5, \quad 30 \%$ & $1.5, \quad 2.6 \%$ \\
\hline 32 & 6 & $60 \%$ & $5 \%$ \\
\hline 55 & 13 & $100 \%$ & $14 \%$ \\
\hline 73 & 20 & $100 \%$ & $26 \%$ \\
\hline
\end{tabular}




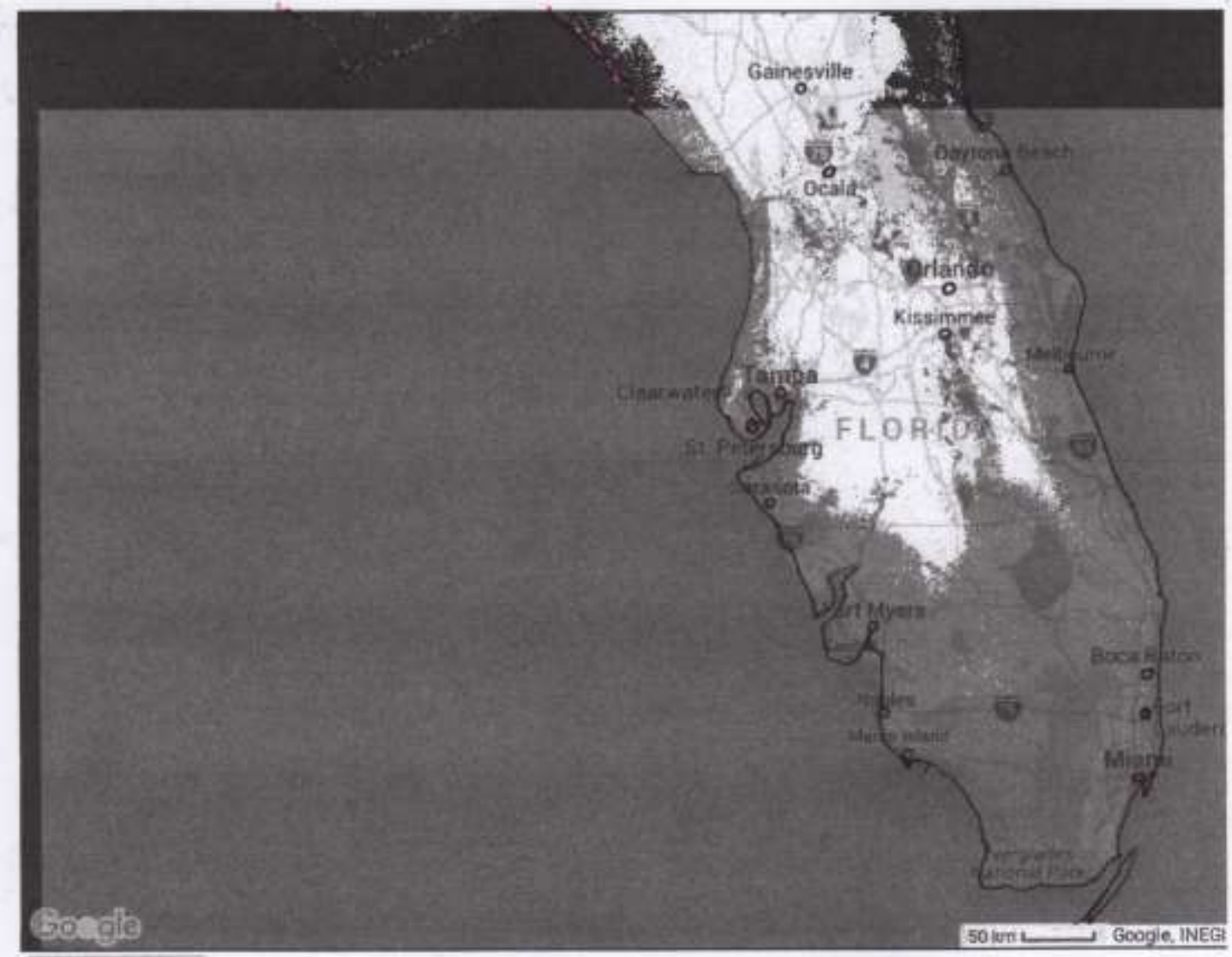

Figure 2: Inundation of the Florida peninsula by a $20 \mathrm{~m}$ sea level rise. Dotted areas are assumed to be subject to destructive flooding but are not inundated at all times. NASA data provided by Google,INEG.

\section{[2] TRIGGERING THE LAST ICE AGE IN NORTHEASTERN CANADA}

\section{[2.1] An extreme change in regional circulation}

The oceanic and geological records show that a unique atmospheric circulation pattern would have existed in eastern Canada for about 500yrs at the start of the last ice age. This persistent low pressure storm system, a strong Labrador Low, is the same as that which would prevail if new Canadian glaciation begins in the next several decades. Figure 3 shows the Labrador Low located over the region west of Greenland. The storm system represented by this hypothetical pattern of low pressure isobars explains the extremely heavy precipitation inferred from large amounts of Canadian erosion recorded in a deep-sea sediment core over a $500 y$ r interval $120,000 y r s$ ago[12]. During this time a rapid ice sheet buildup is indicated by a rate of sea level fall of about $0.5 \mathrm{~cm}$ per year, as derived from surveys of fossil coral formations on the elevated coast of Barbados[5, 13]. This rate is inferred from a $2.4 \mathrm{~m}$ sea level fall that began at the surface of a low-tide fossil barrier reef formed at the stable sea level of the last interglacial, and ended about 500yrs later at a wavecut notch and shelf formed during a brief still-stand of sea level. This brief interruption in sea level fall was most certainly caused by renewal of strong Norwegian Current flow that broke up and melted the unstable glacial ice dome that had accumulated in the shallow Barents Sea north of Norway (Figure 4).

The low-pressure cyclonic circulation was generated by the temperature and density contrasts between the warmer air rising over an ice-free Labrador Sea and Baffin Bay and the colder air over surrounding cold lands that were quickly covered by glacial ice sheets as snow accumulated. The land-sea temperature contrast probably maintained the cyclonic circulation through most of the year, including summer. The inflow of warmer moist air from the Irminger Current that enters the Labrador Sea would have contributed to the rising air that drove the cyclonic flow. The circulation pattern would have been somewhat like a low latitude hurricane with widespread cloud cover. But hurricanes travel onward, and the lasting land-sea temperature contrasts would have tended to anchor this system to the Labrador Sea and Baffin Bay. 


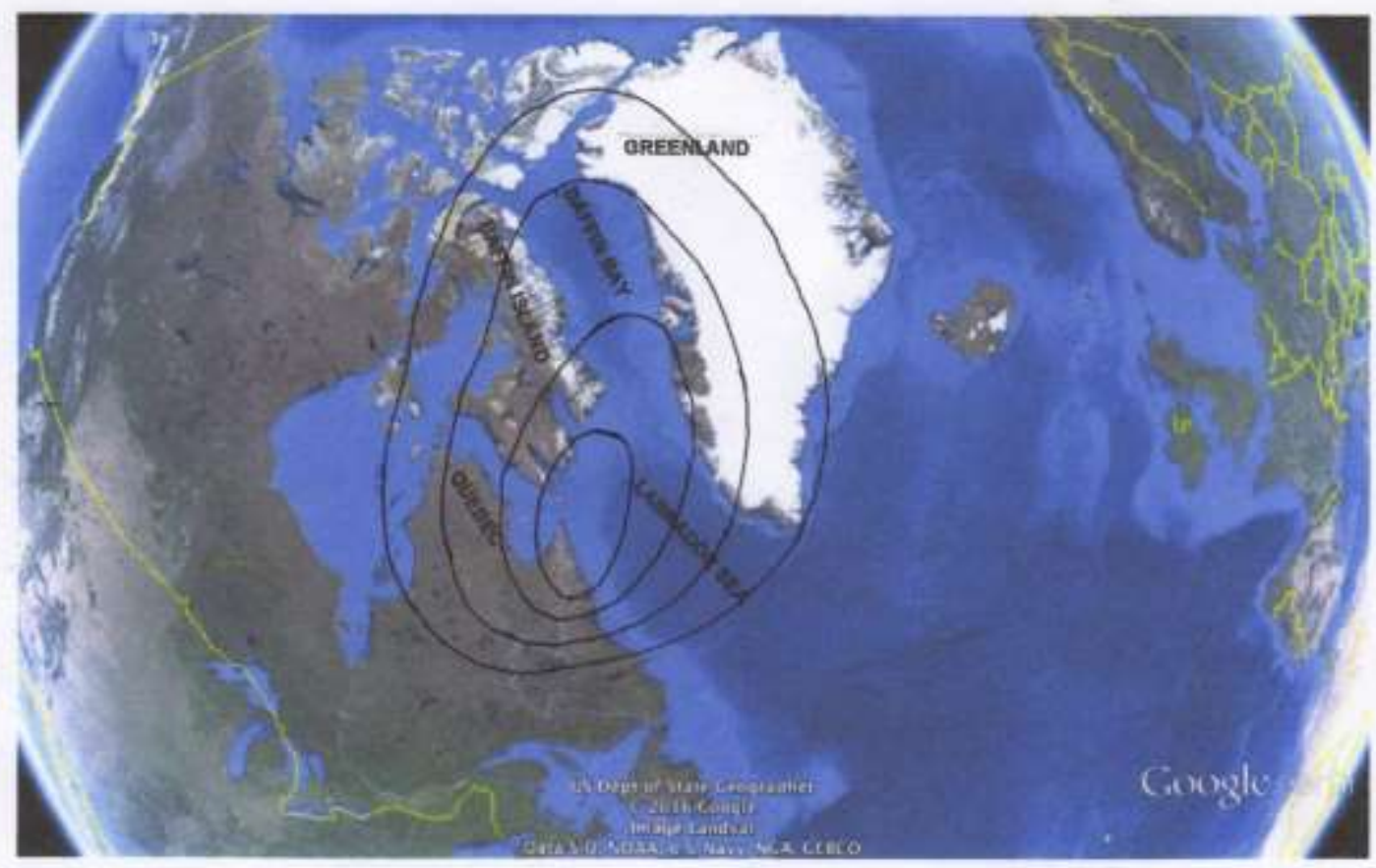

Figure 3: Google Earth image of the Baffin Island area where ice age initiation occurs. Hypothetical isobars define the persistent storm system maintained by large temperature contrasts between the cold land areas that surrounded the sea area that was much warmer than today west of Greenland. Snow covered areas are modern and not indicative of the heavy snow covered areas where ice sheet growth began in Baffin Island, northern Quebec and Labrador, Greenland, and the Barents Sea.

\section{[2.2] The end of the 500yr triggering interval}

The broad counter-clockwise flow around the strong Labrador Low system would have prevented the development of the neighboring Iceland Low pressure system, which normally pumps warmer air into northern Europe and Scandinavia and strengthens the flow of the Norwegian Current. Consequently for about $500 y$ rs northern Europe and Scandinavia remained much colder and the pollen of temperate climate trees such as oak, elm, and linden disappeared from the sediment record of a lake in northern Germany[14]. At the end of the cold triggering interval the Labrador Low became weak, the Iceland Low and a strong Norwegian Current were restored, the thick potentially unstable ice dome on the frozen Barents Sea broke up and melted, and warmth returned to northern Europe. The climate there remained temperately warm for another 3000 years. But the positive feedback provided by thick ice sheets over Baffin Island and northern Quebec and Labrador enabled Canadian ice sheet growth to continue at a slower rate.

\section{[3] GENERATING AN ICE-FREE BAFFIN BAY AND LABRADOR SEA}

\section{[3.1] An ice-free Baffin Bay caused by lack of stratification}

The key to the persistent cyclonic pattern of Figure 3 is the warmer water of the sea west of Greenland that remained ice-free throughout the year. Today all of Baffin Bay and much of the Labrador Sea are icecovered during the long winter season, and are cold even in summer. The small land-sea temperature contrast has little effect on the atmospheric flow. Formation of the sea ice occurs in winter because a nearsurface stratification prevents deep convection and enables surface water to cool to the freezing point. The stratification is caused by the fresher and lower density polar ocean water that enters Baffin Bay through the Nares Strait (Figure 4) and mixes into the upper layers of denser Atlantic water that flows northward along Greenland's west coast. The inflows to Baffin Bay are balanced by the cold Canadian Current outflow that carries winter sea ice southward to Newfoundland and beyond. If the low-density polar water inflow through the Nares Strait does not occur, the stratification is lost, and sea ice cannot form to any significant extent. The West Greenland Current then warms the sea surface and generates the persistent cyclonic counterclockwise flow pattern. Today an infrequent lower atmospheric pressure over the polar ocean can temporarily stop the southward flow in the Nares Strait, but this is seldom observed. A more realistic alternative to explain the loss of stratification is the replacement of polar water in the Nares Strait by denser and more saline Atlantic water of the Spitsbergen-Atlantic Current (SAC) that began to flow westward along Greenland's north coast. This hypothesis is strongly supported by the physics of oceanic circulation and by historical events. 


\section{[3.2\} Baffin Bay stratification destroyed by a strong SAC flow}

The northward flow of the SAC along the edge of the shallow Barents Sea shelf (Figure 4) is driven to a significant extent by the replacement of cooling water that sinks in winter between Spitsbergen and northern Greenland. The SAC flow becomes stronger when the salinity of the sea surface east of northern Greenland becomes greater, thus increasing the surface water density and causing the winter sinking rate to be higher. The sinking water is part of Broecker's well known "conveyor belt" oceanic circulation[15] in which Gulf stream water that sinks to intermediate depths east of Greenland is carried southward to the Southern Ocean. The more saline surface water east of Greenland originates from the Mediterranean outflow, and from the warm Gulf Stream water in the North Atlantic Drift. Upwelling of relatively lower salinity water off the west coast of Africa also contributes, but it has a negative effect on the salinity of the Drift[16]. Water from these three sources mixes and is carried northeastward by the Norwegian Current, part of which tends to be pulled northward as the SAC flow to replace the sinking conveyor-belt water. The Norwegian current is also driven northeastward by counterclockwise storm wind stresses associated with the Iceland Low. Such storms, driven by pressure differences associated with temperature contrasts, are stronger when surface water near Norway is warmer, and the surface there becomes warmer when the storms are stronger. The variable effects of storms therefore cause variations in the seasonal strength of the SAC flow and its northerly extent. Nevertheless, on average a small increase or decrease in salinity of any one of the three source waters can significantly change the strength of the SAC flow and its northward extent in winter.

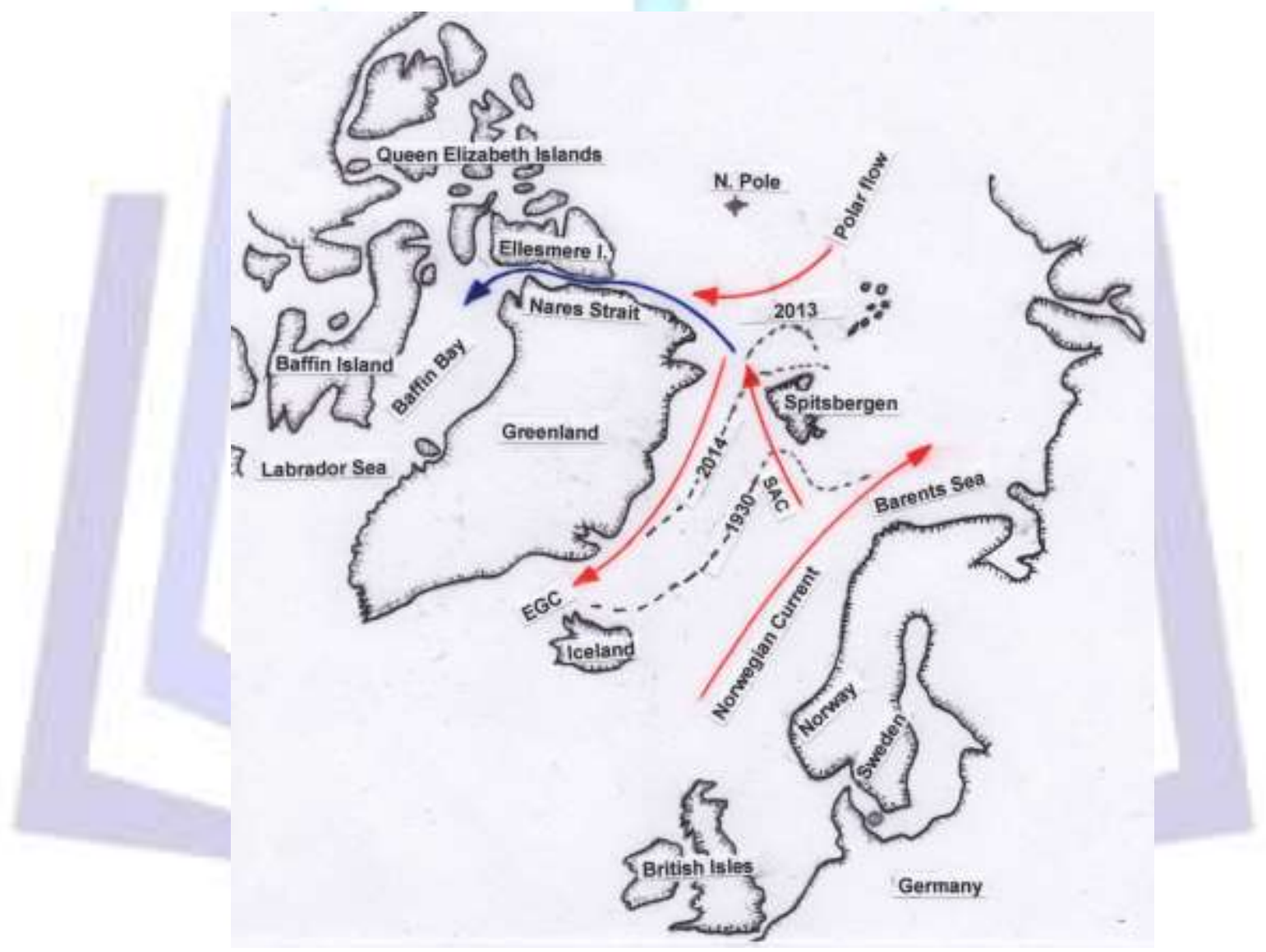

Figure 4: Polar map showing the southerly limit of winter sea ice, dotted lines, determined by the strength of the SAC flow for years around 1930 from Lamb[23], and two recent years from satellite images. The blue line is the predicted extension of the open water of the SAC flow. See text. Note how the counterclockwise wind flow of the Iceland Low centered on Iceland would tend to drive the Norwegian Current northeastward.

If the SAC flow becomes quite strong it can overshoot into the polar ocean, block the southward movement of polar ice, and flow onward into the sea north of Greenland (Figure 4). The variation of the low-salinity source water upwelling off the African coast is cyclic[16]. Consequently the salinity of the sea east of Greenland and therefore the variation of the SAC flow is also cyclic, with a periodicity of almost $1500 \mathrm{yrs}[16$, 17]. The last salinity maximum occurred around the year $1000 A D$ and the SAC flow would have been strong. At that time early Norse traders were able to sail around the northern coast of Greenland in relatively ice-free water. This is known from the map in Figure 5, recovered from a Church archive in World War II[18]. The map shows Greenland realistically as an island, and is probably a copy of an older map drawn by 
Bishop Erik Gnupsson who visited North America during a trading voyage in the year 1118[19]. However the amount of Atlantic water entering Baffin Bay then was insufficient to initiate new Canadian glaciation, probably due to a weak salinity maximum of the sea surface east of Greenland. But the salinity is now increasing due to loss of Mediterranean river inflows used for irrigation[20], and a much stronger SAC flow than in 1118 is anticipated. The essential steps from the diversion of Mediterranean rivers for irrigation to open water north of Greenland are given in Figure 6.

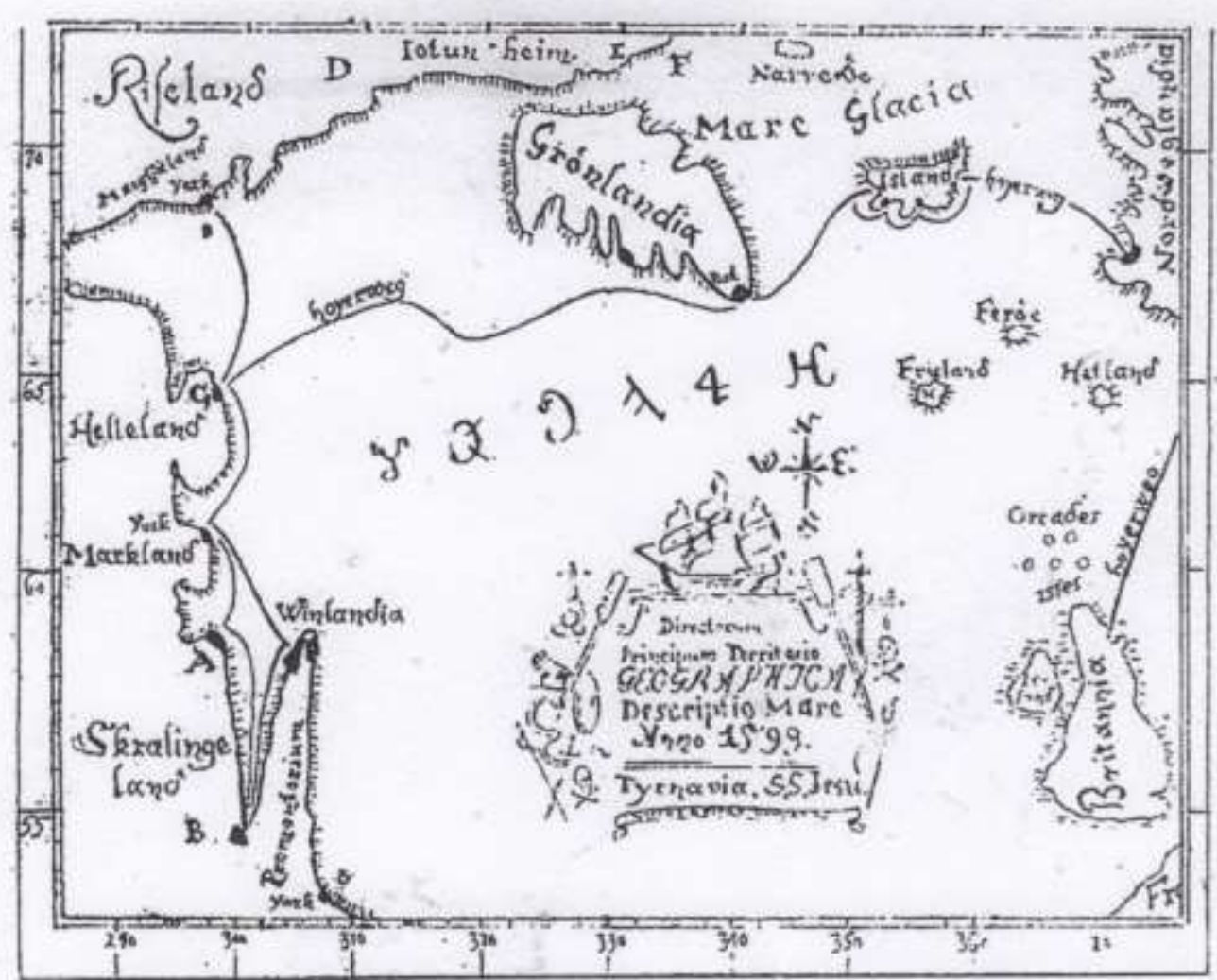

Figure 5: The island of Greenland as depicted on a map that is apparently a copy of information from an older map, now lost, a map drawn by Bishop Erik Gnupsson depicting his 1118 AD voyage to Greenland and Vinland in North America. This map was recovered from a Church archive during World War II and published by Helge Ingstad[18].

The next salinity maximum in its 1500 year cycle will occur shortly before 2500 AD. But the salinity east of northern Greenland would likely be much higher than today at an earlier date because the cycle is being accelerated by rising salinity in the Mediterranean Sea. Consequently the ice age initiation hypothesis might be successfully tested much earlier, possibly before the year 2100 and before extreme greenhouse warming occurs. The possibility of such an early test depends on the measured increasing salinity of the Mediterranean Sea[20]. When extrapolated to the year 2015 this increase over the last 45 years implies an increase of about $3.1 \%$ in the salinity difference between the Atlantic and the Mediterranean that drives the outflow at Gibraltar, and the increase continues. The saline Mediterranean outflow makes an important contribution to the salinity of the high latitude northern North Atlantic [21,22] and to the sea surface east of Greenland. The salinity of the outflow has been increasing more rapidly since most of the inflow waters of Mediterranean rivers were diverted for irrigation purposes in the mid or latter 1900s. The use of nearly all of the Nile River flow for irrigation is an obvious example of this. In the half century since the Aswan high dam on the Nile was completed, the usual maximum northward extension of the SAC flow in winter has increased from the southern tip of Spitsbergen[23] to more than $300 \mathrm{~km}$ beyond the northern coast (Figure 7). More than $50 \%$ of the Fram Strait between Spitsbergen and northeast Greenland was ice-free at the maximum of the SAC flow in 2016 that has usually occurred in midwinter when presumably the sea surface cooling and the sinking rate of the conveyor belt circulation is at a maximum. The rise of Mediterranean salinity will continue for another century while mixing establishes a new higher Mediterranean salinity consistent with the loss of fresh water input, and while greenhouse warming increases the evaporation rate. By the year 2100 the increasing Mediterranean salinity implies an increase of $8 \%-10 \%$ in the Mediterranean/Atlantic salinity difference that drives the outflow relative to1970. 


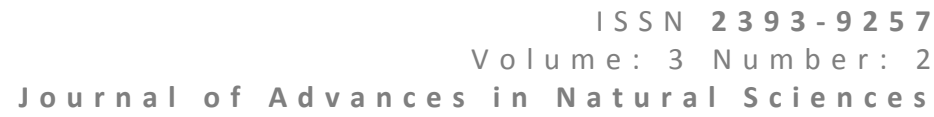

The SAC flow replacement rate increases. Its saltier water
from the Norwegian current is now carried northward into
the polar ocean beyond Spitsbergen in winter. In future
decades the SAC flow may reach to the north of Greenland.<smiles>C=CC</smiles>

Saltier surface water between Spitsbergen and Greenland sinks at a greater rate in winter.

The salinity of surface water, drawn from the Norwegian Current to the area between Spitsbergen and Greenland, increases.<smiles>[12CH]=C[Te]</smiles>

The salinities of the North Atlantic Drift and the Norwegian Current increase.<smiles>CCCCC</smiles>

A measured increase in salinity of the Mediterranean

Sea occurs. Salinity and rate of the outflow at Gibraltar are likewise continuing to increase.<smiles>C=CC</smiles>

In the $20^{\text {th }}$ century, most river inflow to the Mediterranean is diverted for irrigation.

Figure 6: Steps connecting the salinity of the lower latitude Mediterranean Sea with the salinity in the higher latitude Greenland Sea where winter-cooled water sinks and drives the Spitsbergen-Atlantic Current (SAC) northward.

The resulting increase in salinity where winter water sinks northeast of Greenland is not likely to be much reduced by glacial melt water from Greenland's east coast. Northward Drift velocities calculated by Greatbatch and $\mathrm{Xu}[24]$ indicate that the mixed Mediterranean outflow water remains to the east as it rises and enters the Norwegian Current, which supplies the excess salt that allows the conveyor belt water to sink. But the melt water tends to be carried out of the region by way of the East Greenland Current (Figure 7) through the Denmark Strait, which minimizes mixing into the Norwegian Current. The greater northward SAC flow that results from the increasing Mediterranean salinity may therefore put Atlantic water of greater salinity off the north coast of Greenland before the year 2100 than at the time of Bishop Gnupsson's voyage, if the trend of northward extension of the SAC flow suggested by Figures 4 and 7 continues. The absence of winter sea ice in Baffin Bay may again become a reality, new ice sheet growth would begin, and the melting loss of Greenland ice would largely cease. 


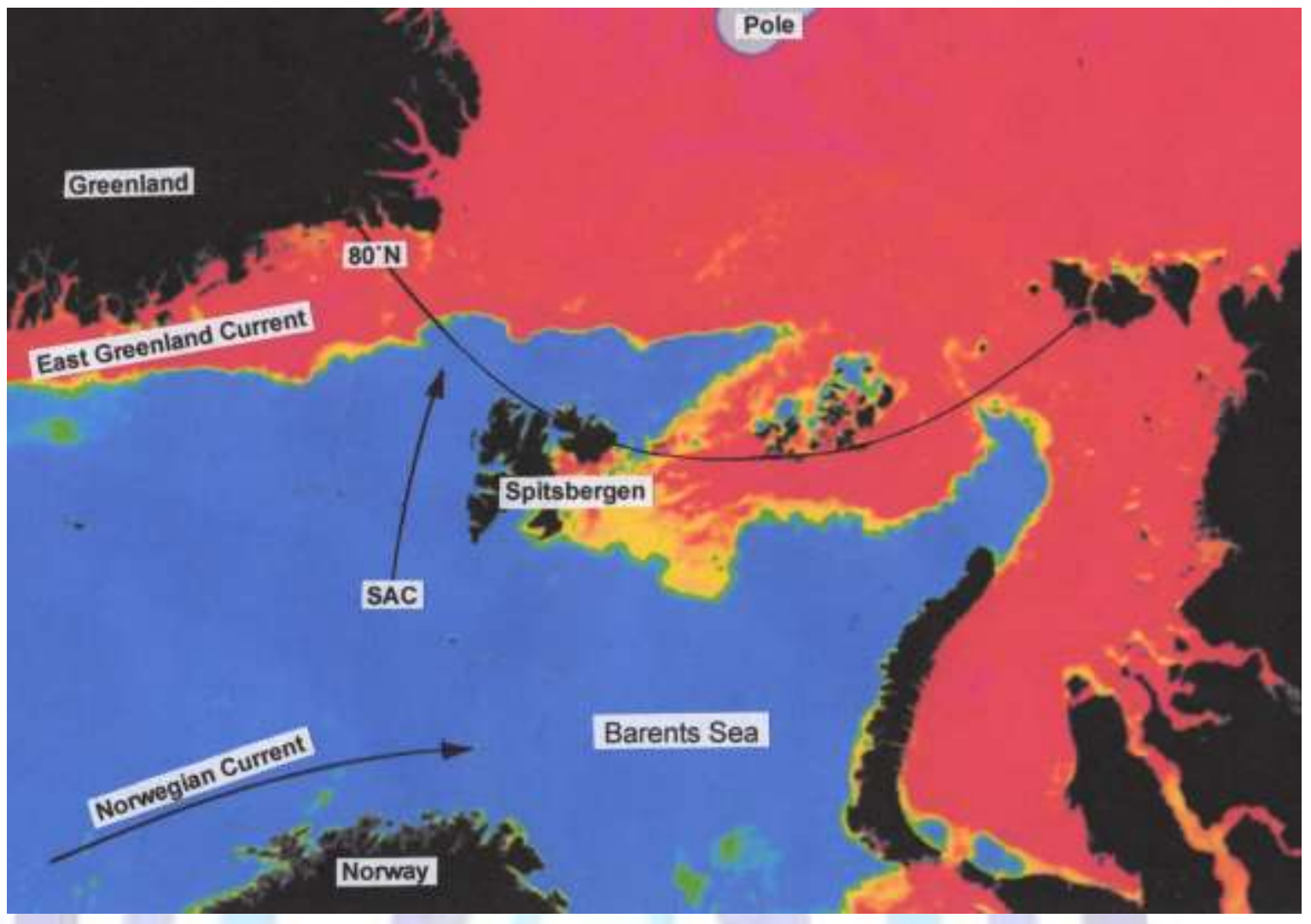

Figure 7: False color image of sea ice (red, yellow) showing winter penetration of the SpitsbergenAtlantic Current into the polar ocean on 28 January, 2016, when the SAC flow was presumably the strongest. The narrowest yellow edging would occur when the SAC flow is pressing most strongly against the multi year polar sea ice. $55 \%$ of the Fram strait at $80^{\circ} \mathrm{N}$ was ice-free. Image posted by Technical University of Denmark.

\section{[4] SUMMARY: AT AN ICE AGE THRESHOLD}

We know by analogy with the last ice age initiation that, if the powerful Labrador Low circulation is again established, enormous amounts of snow will fall on lands west of Greenland, on Greenland itself, and probably also on the frozen Barents Sea area east of northern Greenland. Cloudy skies would minimize summer melting allowing sea level to fall rapidly. Florida would thereby be saved. The northwestern Eurasian temperatures will be generally colder, as inferred from the disappearance of temperate climate trees indicated by the pollen record from a lake in northern Germany[25]. After triggering begins, the ice-free Baffin Bay would be maintained by northward flow of a stronger warmer West Greenland Current[5]. Broecker's conveyor belt flow would slow down because the loss of the wind stresses of the Iceland Low reduces the Norwegian Current flow of salty water to the surface of the sea east of Greenland. The triggering event that would reverse ice loss on Greenland would also tend to delay loss of continental ice on Antarctica because a weaker conveyor belt would indirectly reduce the warming of the Southern Ocean[16]. However, the reversal of rising sea level by new ice sheet growth would not resolve the ultimate issue of the multiple effects of unlimited fossil fuel consumption.

Although the triggering of the powerful cyclonic Labrador Low storm system cannot be predicted with certainty, the trend in that direction is clear, and the steps leading up to the triggering event are known. The measured salinity of the Mediterranean Sea is increasing. Therefore the salinity of the sea surface east of northern Greenland is also increasing. Consequently, over the last 50 to 80 years we are now observing an ever greater northward extension of the Spitsbergen-Atlantic Current into the polar ocean in winter. Its further penetration into the coastal sea north of Greenland, its flow through the Nares Strait, and its possible future removal of winter sea ice from Baffin Bay will be recorded by satellite observation systems and will be observable by anyone in future decades who has access to the internet site of the Technical University of Denmark: (http://www.seaice.dk) or the University of Illinois Cryosphere Today site: (http://arctic.atmos.uiuc.edu/cryosphere). 


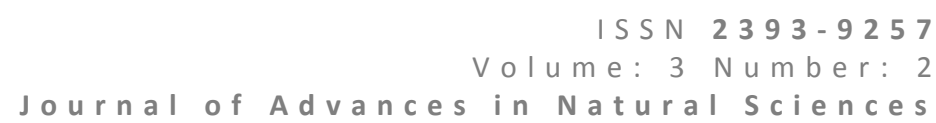

\section{REFERENCES CITED}

[1] Milankovitch, M., 1930, Mathematische klimalehre und astronomische Theorie der Klimaschwankungen, In: Handbuch der Klimatologie, I (A), Berlin, Gebruder Borntraeger.

[2] Rind, D., D. Peteet and G. Kukla, 1989, Can Milankovitch orbital insolation initiate growth of ice sheets in a general circulation model?: Journal of Geophysical Research, v. 94, p. 12851-12871.

[3] Wunsch, C., 2004, Quantitative estimate of the Milankovitch-forced contribution to observed Quaternary climate Change: Quaternary Science Reviews, v. 23, p. 1001-1012.

[4] Berger, A.L., 1978, Long term variations of caloric summer insolation resulting from the Earth's orbital elements, Quaternary Research, v. 9, 139-167. Tabulated values of insolation supplied to author.

[5] Johnson, R.G., 2015a, Initiation of the last ice age in Canada by extreme precipitation resulting from a cascade of oceanic salinity increases, Journal of Advances in Natural Sciences, v. 3, No.1, 238-252.

[6] Rossignol-Strick, M., 1983, African monsoons, an immediate climate response to orbital insolation: Nature, v. 304, p. 46-49.

[7] Fillon, R.H., 1985, Northwest Labrador Sea stratigraphy, sand input and paleoceanography during the last 160,000 years: in: Quaternary Environments, Eastern Canadian Arctic, Baffin Bay and Western Greenland, J.T. Andrews, ed, Allen and Unwin, Boston, p. 212-247.

[8] Koerner, R.M., J.C. Bourgeois, and D.A. Fisher, 1988, Pollen analysis and discussion of time-scales in Canadian ice cores: Annals of Glaciology, v. 110, 85-91.

[9] Mouginot, J., E. Rignot, B. Scheuchl, I. Fenty, A. Khazendar, M. Morlighem, A. Buzzi, and J. Paden, 2015, Fast retreat of Zachariae Isstrom, northeast Greenland, Science, 12 November 2015.

[10] Dowsett, H.J. and T.M. Cronin, 1990, High eustatic sea level during the Middle Pliocene: Evidence from the southeastern U.S. coastal plain, Geology, v. 18, 435-438.

[11] Dowsett, H.J., T.M. Cronin, R.Z. Poore, R.S.Thompson, R.C. Whatley, and A.M. Wood, 1992, Micropaleontological evidence for increased meridional heat transport in the North Atlantic Ocean during the Pliocene, Science, v. 258, 1133-1135.

[12] Adkins, J.F., E.A. Boyle, L. Keigwin and E. Cortijo, 1997, Variability of North Atlantic thermohaline circulation during the last glacial period: Nature, v. 390, p. 154-156.

[13] Johnson, R.G., 2001, Last interglacial sea stands on Barbados and an early anomalous deglaciation timed by differential uplift: Journal of Geophysical Research, v. 106, No.C6, p. 11543-11551.

[14] Field, M.H., B. Huntley and H. Müller, 1994, Eemian climate fluctuations observed in a European pollen record: Nature, v. 371, p. 779-783.

[15] Broecker, W.S., 1991, The great ocean conveyor, Oceanography, v. 4, p. 79-90.

[16] Johnson, R.G., 2015b, Did a bi-polar multi-level oceanic oscillation cause the Little Ice Age and other high latitude climate extremes? Journal of Advances in Natural Sciences, v. 3, No. 1, 228-236.

[17 ] Bond, G., W. Showers, Cheseby, R. Lotti, P. Almasi, P. deMenocal, P. Priore, H. Cullen, I. Hajdas, and G. Bonani, 1997, A pervasive millennial-scale cycle in North Atlantic Holocene and glacial climates, Science, v. 278, 1257-1266.

[18] Ingstad, H., 1969, Westward to Vinland, New York, St. Martins Press.

[19] Skelton, R.A., T.E. Marston, and G.D. Painter, 1965, The Vinland Map and the Tartar Relation, New Haven, Yale University Press.

[20] Rohling, E.J. and H.L. Bryden, 1992, Man-induced Salinity and Temperature increases in Western Mediterranean Deep Water: Journal of Geophysical Research, v. 97, p. 11191-11198.

[21] Reid, J.. 1979, On the contribution of the Mediterranean Sea outflow to the Norwegian-Greenland Sea: Deep-Sea Research, v. 26, p. 1199-1223.

[22] Bahr, A., S. Kaboth, F.J. Jiménez-Espejo, F.J. Sierro, A.H.L. Voelker, L. Lourens, U. Röhl, G.J. Reichart, C. Eascitia, F.J. Hermández-Molina, J. Pross, and O. Friedrich, 2015, Persistent monsoonal forcing of Mediterranean Outflow Water dynamics during the late Pleistocene, Geology, v. 43, 951-954.

[23] Lamb, H.H., 1972, CLIMATE: Present, Past and Future, v. 1, Fundamentals and climate now, p. 338, London, Metheun and Co., Ltd. 